BMC

Genomics

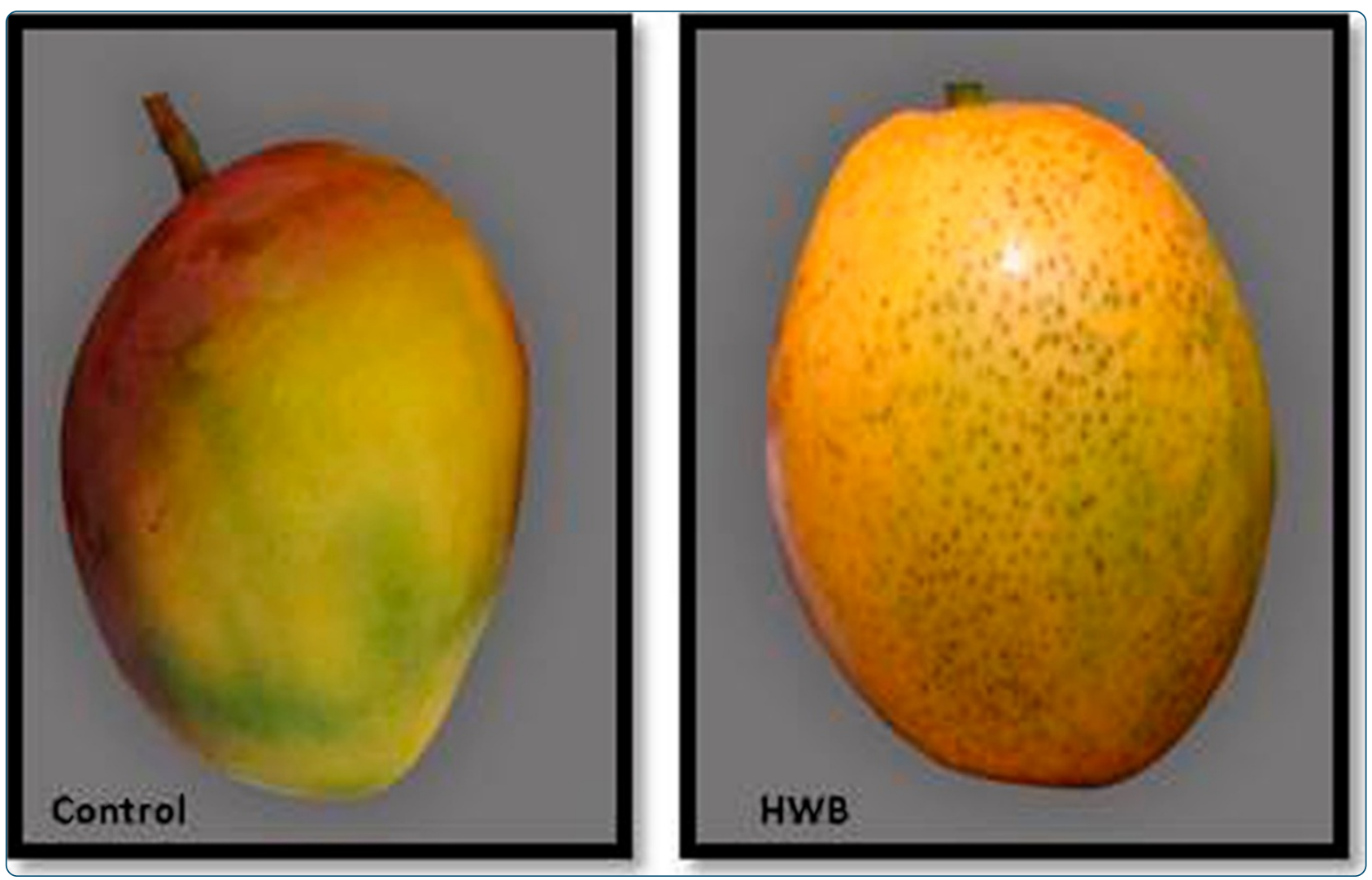

De-novo assembly of mango fruit peel transcriptome reveals mechanisms of mango response to hot water treatment

Luria et al. 


\title{
De-novo assembly of mango fruit peel transcriptome reveals mechanisms of mango response to hot water treatment
}

\author{
Neta Luria ${ }^{1+}$, Noa Sela ${ }^{2 \dagger}$, Mor Yaari ${ }^{1}$, Oleg Feygenberg ${ }^{1}$, llana Kobiler ${ }^{1}$, Amnon Lers $^{1}$ and Dov Prusky ${ }^{1 *}$
}

\begin{abstract}
Background: The mango belongs to the genus Mangifera, consisting of numerous tropical fruiting trees in the flowering plant family, Anacardiaceae. Postharvest treatment by hot water brushing (HWB) for 15-20 s was introduced commercially to improve fruit quality and reduce postharvest disease. This treatment enabled successful storage for 3-4 weeks at $12^{\circ} \mathrm{C}$, with improved color and reduced disease development, but it enhanced lenticel discoloration on the fruit peel. We investigated global gene expression induced in fruit peel by HWB treatment, and identified key genes involved in mechanisms potentially associated with fruit resistance to pathogens, peel color improvement, and development of lenticel discoloration; this might explain the fruit's phenotypic responses.

Results: The mango transcriptome assembly was created and characterized by application of RNA-seq to fruit-peel samples. RNA-seq-based gene-expression profiling identified three main groups of genes associated with HWB treatment: 1) genes involved with biotic and abiotic stress responses and pathogen-defense mechanisms, which were highly expressed; 2) genes associated with chlorophyll degradation and photosynthesis, which showed transient and low expression; and 3) genes involved with sugar and flavonoid metabolism, which were highly expressed.
\end{abstract}

Conclusions: We describe a new transcriptome of mango fruit peel of cultivar Shelly. The existence of three main groups of genes that were differentially expressed following HWB treatment suggests a molecular basis for the biochemical and physiological consequences of the postharvest HWB treatment, including resistance to pathogens, improved color development, and occurrence of lenticel discoloration.

Keywords: Mangifera indica, Transcription profiling, RNA-seq, Induced resistance, Sugar metabolism, Lenticel discoloration, Chlorophyll metabolism, Postharvest diseases

\section{Background}

Mango (Mangifera indica) belongs to the plant family Anacardiaceae, which includes numerous tropical fruiting trees; it is native to South Asia, from where it has been distributed worldwide to become one of the most cultivated fruits in the tropics, with significant economic importance [1,2]. High-quality fruits should be free of external damage, bruises, latex or sap injury, and decay. The storage life of mangoes is limited to 3 or 4 weeks at 10 $15^{\circ} \mathrm{C}[1,2]$, but production and postharvest practices, as well as novel technologies and packinghouse management,

\footnotetext{
*Correspondence: dovprusk@volcani.agri.gov.il

'Equal contributors

'Department of Postharvest Science of Fresh Produce, ARO, the Volcani Center, Bet Dagan 50250, Israel

Full list of author information is available at the end of the article
}

contribute greatly to retention of the fruit's external quality throughout the worldwide supply chain $[2,3]$.

Mango losses after harvest are caused by: harvesting at inappropriate stages of fruit maturity, mechanical damage during harvesting or through improper field handling, sap burn, discoloration of lenticels, fruit softening, chilling injury, and/or disease development and pest damage [4-8]. Two main factors affecting fruit quality are lenticel discoloration and postharvest disease [9].

Lenticel discoloration is a superficial blemish that affects some cultivars, imparting a speckled appearance to the fruits, which then are regarded as less desirable and are downgraded, although the speckled appearance does not affect fruit internal quality. Blemish development is limited to the lenticel perimeter and the immediately 
adjacent area, and does not extend deeper than the outermost layers of the rind [10].

Postharvest diseases reduce fruit quality and result in severe losses [11]. In Israel, the main postharvest disease is alternaria black spot (ABS), caused by the fungus Alternaria alternata, which penetrates the fruit during its growth and is affected by the relative humidity in the orchard [12,13]; following penetration, the fungus remains quiescent until fruit harvest and ripening $[14,15]$. Stem-end rots that occur following long periods of storage are caused in Israel, mainly by Phomopsis mangiferae $[12,16]$.

Control of postharvest development of side rots caused by $A$. alternata, and stem-end rot caused by $P$. mangiferae, has been achieved by adopting a series of postharvest management practices, including hot-water brushing (HWB) for 15-20 s [2] and, in some cases, application of acid prochloraz and waxing with a polyethylene emulsion [2]. This treatment enables commercially successful storage for 3-4 weeks at $12^{\circ} \mathrm{C}$ and ripening for an additional week at $20^{\circ} \mathrm{C}$.

We recently demonstrated that HWB stresses the fruits and activates processes that could reduce fruit quality after storage [9]. The objective of the present study was to use gene-expression profiling to elucidate the biological mechanisms activated in mango by HWB and that mediate fruit quality and resistance to postharvest diseases. Mango fruits of cultivar Shelly were subjected to a commercial HWB procedure followed by a detailed transcriptomic analysis that used nextgeneration sequencing platforms. The differential geneexpression profiles of treated fruits indicated several transient HWB-regulated mechanisms, including: expression of host-resistance to pathogens related genes; transient decrease in the expression of chlorophyll catabolism- and photosynthesis; and a late decrease in the expression of genes that modulate processes related to glucose and flavonoid metabolism. The present data suggest fine control of the fruit response by the HWB exogenous treatment associated with packinghouse handling that may strongly modulate fruit quality during storage.

\section{Results and discussion}

\section{Characterization of mango transcriptome assembly}

The mango is a member of the family Anacardiaceae and is an allotetraploid $(2 \mathrm{n}=40)$ fruit tree with a small genome size of about $450 \mathrm{Mbp}$ [17]. A new mango transcriptome was assembled from 8.6-Gbp sequence data (coverage of 190-fold) by using Trinity [18] software, which generated 57,544 contigs with N50 of 1,598 bases and an average length of 863.3 bases (Figure 1A). To identify the putative functions of assembled transcripts, a sequence-similarity search was conducted against the NCBI non-redundant (NR) database by using a BLASTx search with a cut-off $E$ value of $10^{-5}$. A total of 35,719

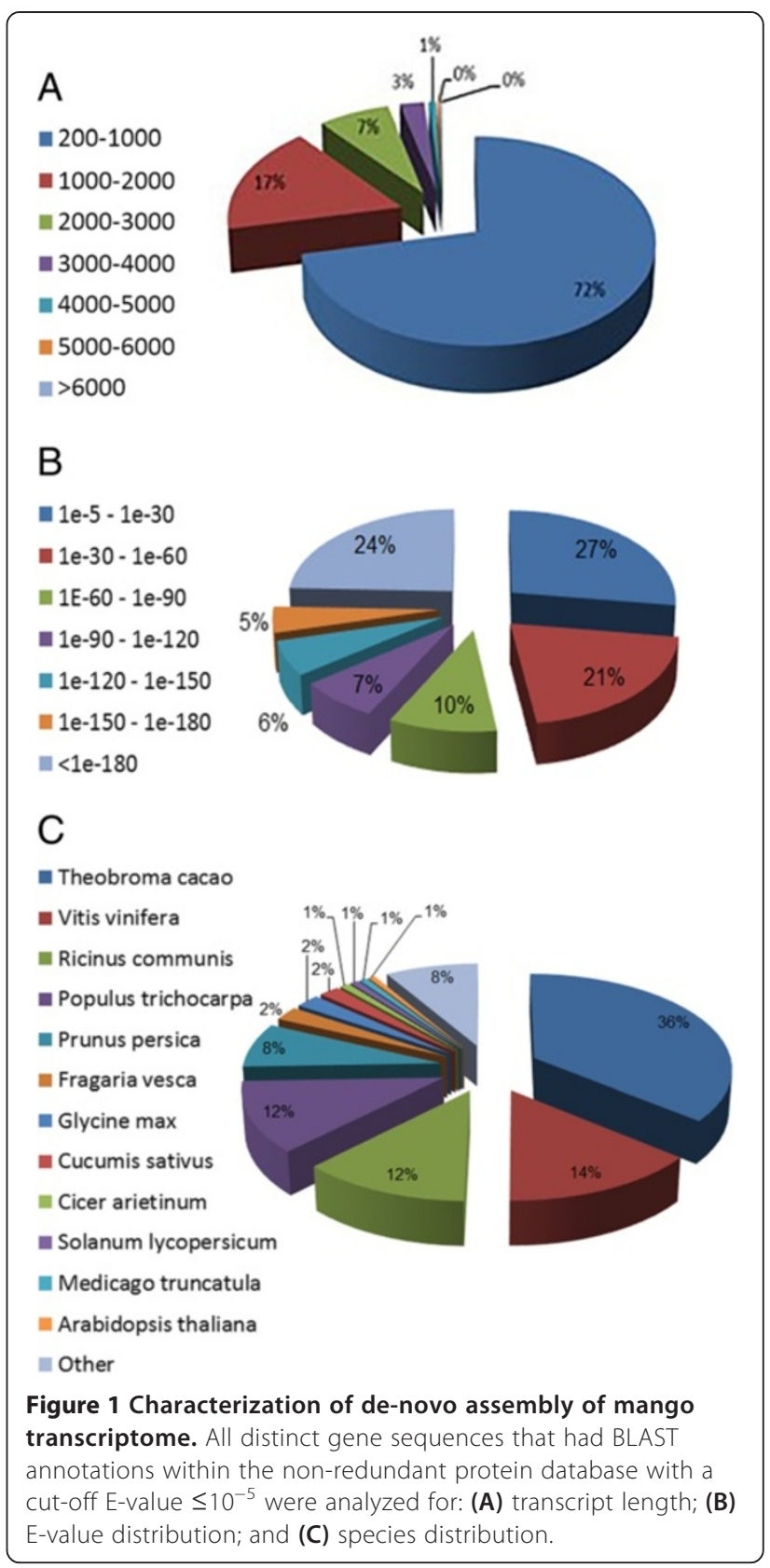

transcripts (62.07\%) showed significant similarity to known proteins in the NR database. Based on the NR annotations, $53.12 \%$ of the annotated sequences showed very high homology $\left(E\right.$-value $<10^{-60}$ ), and $20.9 \%$ showed high homology $\left(10^{-60}<\right.$ E-value $\left.<10^{-30}\right)$. An additional $25.9 \%$ showed homology $\left(10^{-30}<\mathrm{E}\right.$-value $\left.<10^{-5}\right)$ to available plant sequences (Figure 1B). With respect to species, 35.9 and $14.2 \%$ of the unique sequences had top matches to sequences from Theobroma cacao and Vitis vinifera, respectively, with additional hits to Ricinus communis (12.1\%), Populus trichocarpa (12\%), Prunus persica (7.5\%), Fragaria vesca (2.3\%(, Glycine max (2.2\%) and Cucumis sativus (1.8\%) (Figure 1C). Gene ontology 
(GO) [19] was used to classify the functions of the predicted mango genes. Based on sequence homology, a total of 28,317 transcripts (49.2\%) could be categorized into one of three main categories: biological process, cellular component, and molecular function (Figure 2).

\section{Profiling the expression of mango genes following HWB treatment}

The variation in gene-expression profiles in mango fruit harvested at the mature-green stage was analyzed comparing the gene expression immediately after HWB (10-20 min considered as time 0), and at 4, 17 and $48 \mathrm{~h}$ after the treatment with those of untreated fruits at the same time points. Both HWB and control fruits were stored at $12^{\circ} \mathrm{C}$. Two basic criteria were used to define differential gene expression: a twofold difference in transcript levels between treated and control fruits, and a $P$-value $<0.05$ after false-discoveryrate (FDR) determination (Additional file 1: Table S1, Additional file 2: Table S2, Additional file 3: Table S3, Additional file 4: Table S4).

Analysis of gene responses revealed a decrease in the number of differentially expressed genes from time 0 to $48 \mathrm{~h}$ : immediately after HWB treatment (10-20 min was considered as $0 \mathrm{~h}) 827$ genes were differentially expressed whereas $48 \mathrm{~h}$ later only 87 genes showed differential expression (Table 1). Venn diagrams (Figure 3) of the differential expression at the four different sampling times showed that most of differentially expressed genes are unique to one of the time points.

The expression patterns of 1,225 genes that were differentially expressed in at least one time point were subjected to hierarchical clustering, which resulted in five main clusters (Figure 4A), which then were visualized on a heat map (Figure $4 \mathrm{~B}$ ). The first cluster contained 343 genes, and clusters 2 through 5 contained 370, 120, 245, and 147 genes, respectively (Figures 4A,B). The expression patterns shown in Figures $4 \mathrm{~A}$ and $4 \mathrm{~B}$ indicate that, compared with their controls: cluster 1 showed increased transcript abundance at times 0 and $4 \mathrm{~h}$ and decreased abundance at times 17 and $48 \mathrm{~h}$; cluster 2 was characterized by a transient increase in transcript abundance at time $0 \mathrm{~h}$ and decreases to almost no change at times 4, 17 and $48 \mathrm{~h}$; cluster 3 showed transient up-regulation at $0 \mathrm{~h}$ and down-regulation at $17 \mathrm{~h}$; cluster 4 was characterized by down-regulation of transcript abundance at 0 and $4 \mathrm{~h}$, less marked down-regulation at $17 \mathrm{~h}$, and almost returned to equal expression in treated and control fruits at $48 \mathrm{~h}$ after the treatment; cluster 5 showed an increased gene expression from time 0 to 4 which is maintained through $48 \mathrm{~h}$.

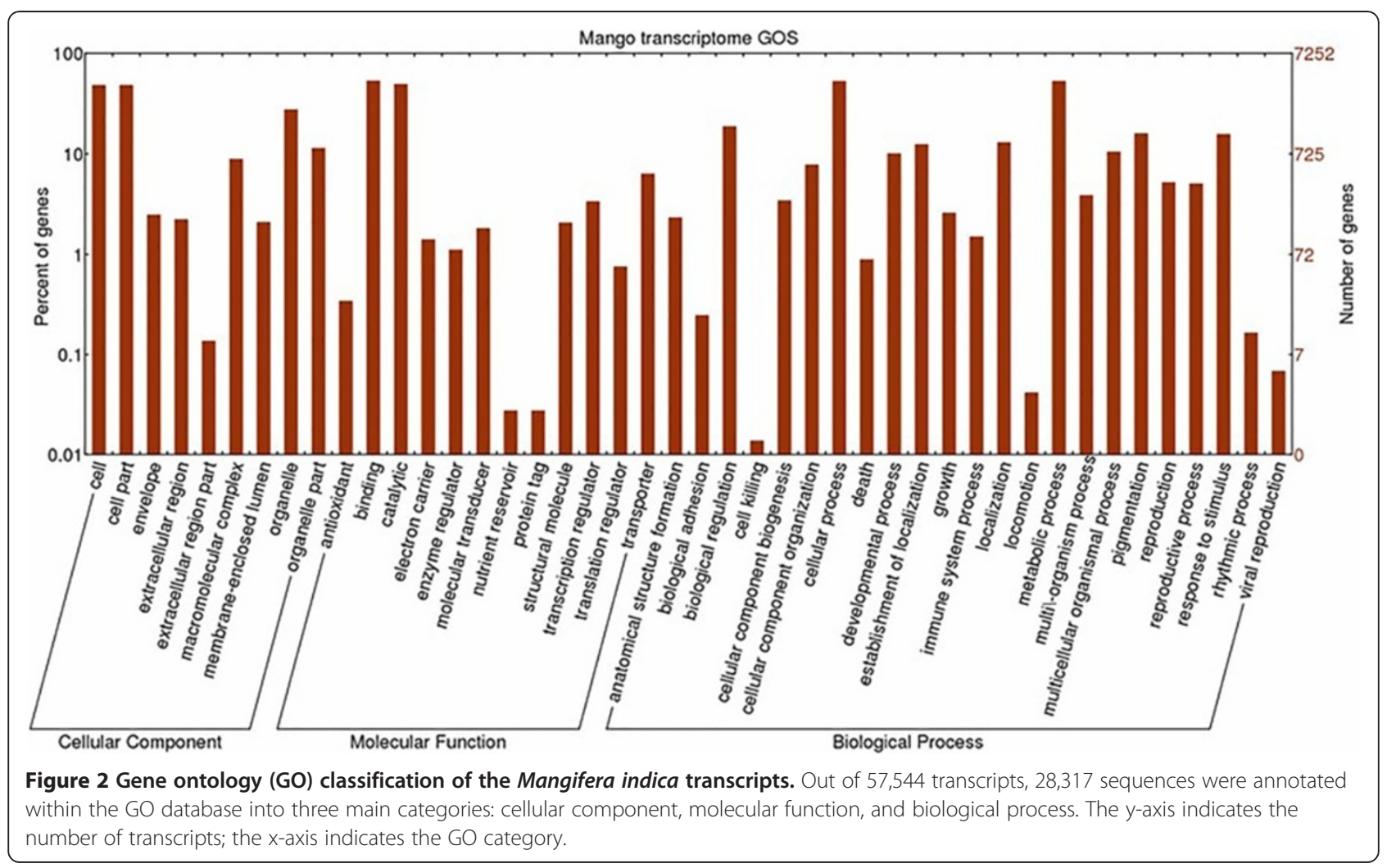


Table 1 Summary of differentially expressed genes following HWB treatment

\begin{tabular}{cccc}
\hline $\begin{array}{c}\text { Time point after } \\
\text { treatment }(\mathrm{h})\end{array}$ & $\begin{array}{c}\text { Number of } \\
\text { transcripts } \\
\text { with increased } \\
\text { abundance }\end{array}$ & $\begin{array}{c}\text { Number of } \\
\text { transcripts with } \\
\text { decreased } \\
\text { abundance }\end{array}$ & Total \\
\hline 0 & 99 & 728 & 827 \\
4 & 141 & 195 & 336 \\
17 & 137 & 38 & 175 \\
48 & 17 & 70 & 87 \\
\hline
\end{tabular}

Analysis of over-represented gene ontology (GO) terms in the subset of differentially expressed genes relative to the mango transcriptome database

Each cluster was analyzed for its GO-enriched profile using BLAST2go and Fisher's Exact Test (Additional file 5: Table S5). Cluster 1 (Figure 4A) was characterized by a transient increase in the expression of genes involved in defense against pathogens as well as in chitinase and amino-glycan activities (Additional file 5: Table S5). Genes that possibly are involved in inhibition of fungal growth by direct modulation of host structural changes as well as by induced host resistance were selected for further analysis [20]. This suggests that the HWB treatment induces fruit responses similar to those observed to be induced following pathogen invasion and during induction of transient stress resistance.

Cluster 2 were highly represented genes encoding for enzymes associated with flavanoid biosynthesis and metabolism, such as chalcone-flavanone isomerase family protein isoform 1 (EC:5.5.1.6) and flavonol synthase flavanone 3-hydroxylase-like (EC:1.14.11) [21]. Cluster 2 also included malic enzyme activity, such as NADP-dependent malic enzyme-like (EC:1.1.1.38), that catalyzes oxidative decarboxylation of malate to pyruvate [22].

Cluster 3 was enriched with genes associated with the cellular defense response and its regulation; in this cluster we found genes such as allene oxidase synthase (AOS) (EC:4.2.1.92) and syntaxin 121 (Syn121) [23].

Cluster 4 was enriched with genes involved in photosynthesis and chlorophyll catabolism, whose abundance decreased as sampling times increased from 0 through $17 \mathrm{~h}$ (Figure 3, Additional file 5: Table S5). Among the genes with reduced expression, encoding for protein that might contribute to the reduction of chlorophyll level in the fruit were chlorophyll a-b binding protein chloroplastic-like (LHCIIb) (EC4.99.1.1) [24,25] and light-harvesting complex i protein (lhca2) [26], which resides in the chloroplast thylakoid membrane; also in this cluster was the gene photosystem i reaction center subunit chloroplast (PIRC) (EC1.97.1.12) [27]. Cluster 5 was not enriched with any GO classification term.

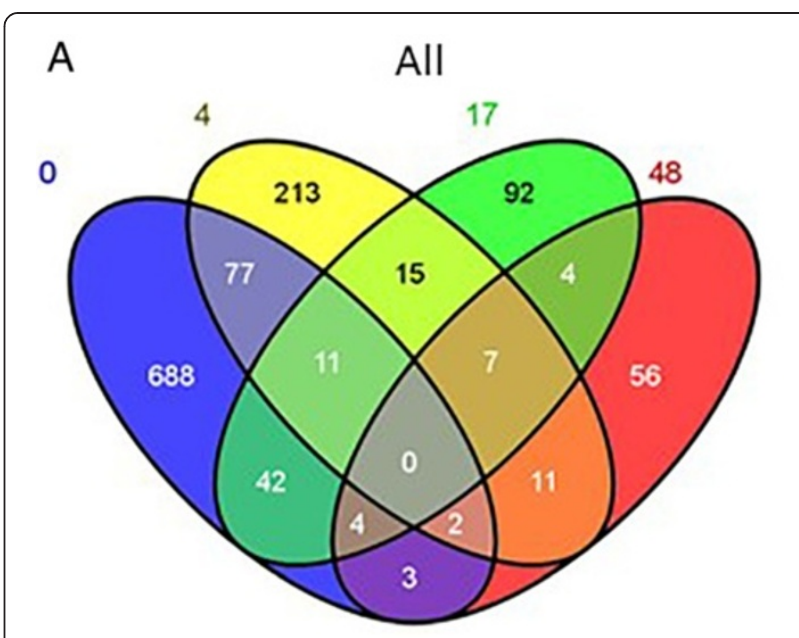

B

Up-regulated

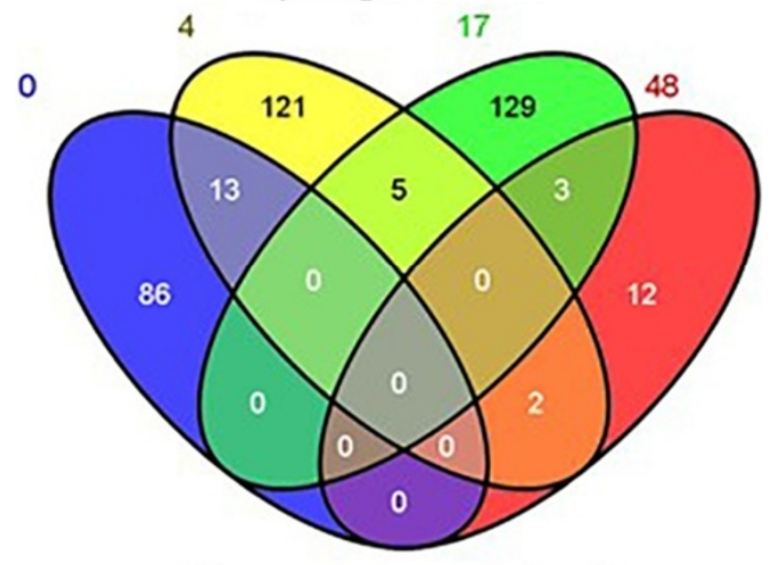

C
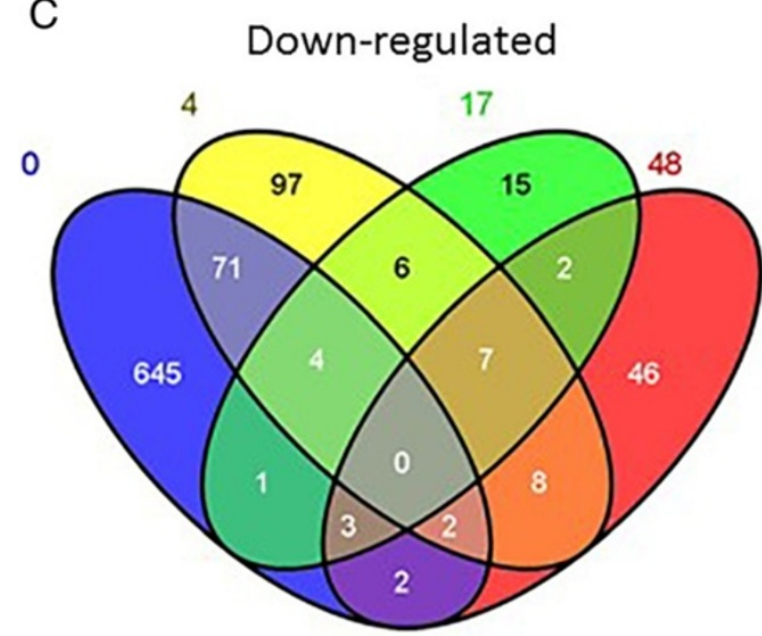

Figure 3 Venn diagram showing number of overlapping and non-overlapping differentially expressed mango fruit genes at different sampling times after HWB treatment. (A) All differentially expressed genes; (B) differentially expressed genes that were upregulated; (C) differentially expressed genes that were downregulated. Fruit tissue was sampled at 0, 4, 17 and $48 \mathrm{~h}$ after the HWB treatment, and compared with that of untreated fruits sampled at the same time points. 


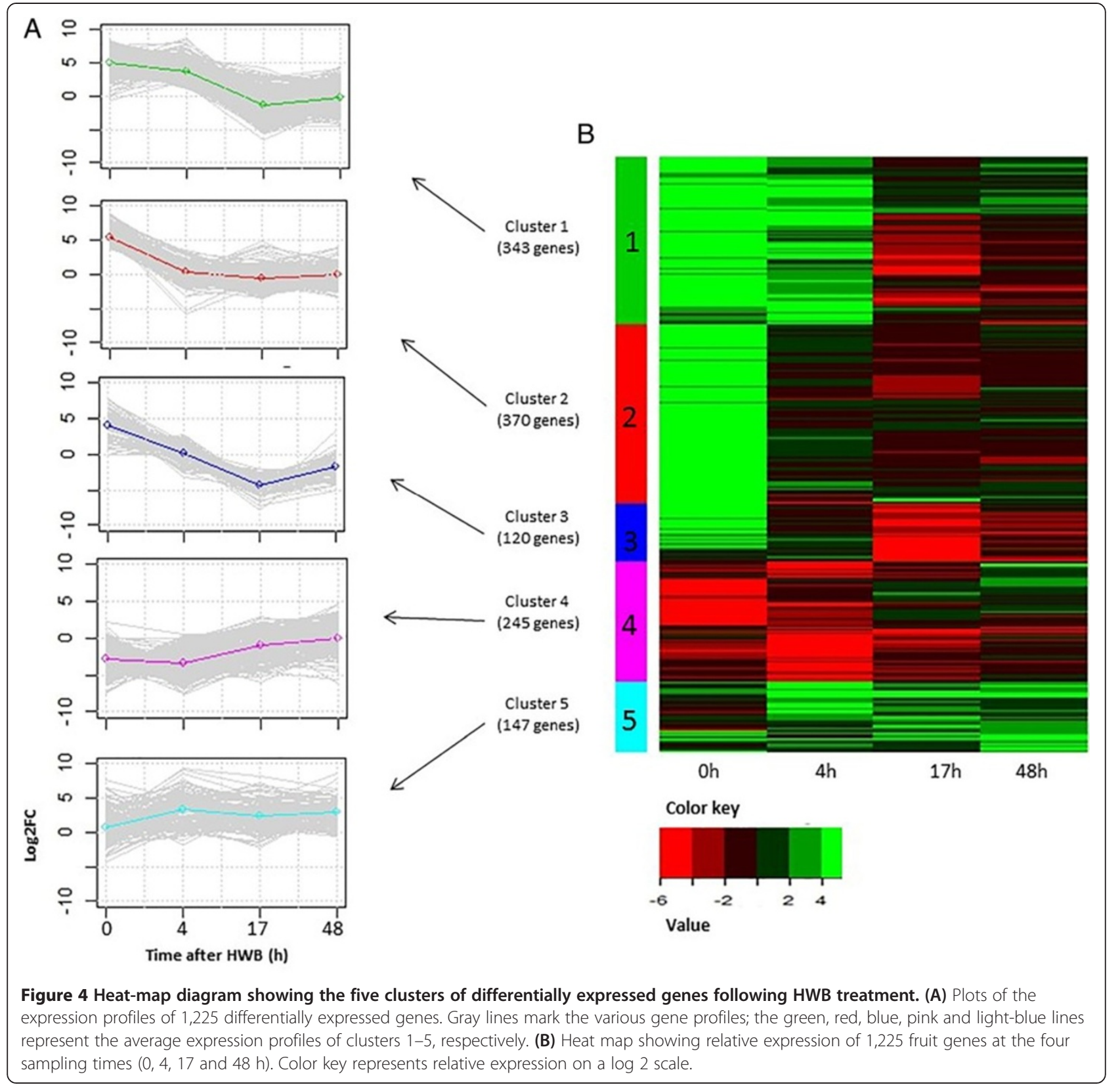

\section{Validation of differential gene expression}

To validate the differential expression of specific genes identified by the RNA-seq analysis, quantitative (q) RTPCR analyses were performed for key genes of interest. Mango genes belonging to the five different clusters of genes that were differentially expressed following HWB treatment were analyzed for their expression levels (Figure 5). Chitinase 7 (EC:3.2.1.14) and phenylalanine ammonia lyase $(P A L)$ (EC:4.3.1.25; EC:4.3.1.24) genes involved in chitinase activity and response to wounding were represented in cluster 1 (Figures 5A,B). Oxysterol binding protein $(O x y B P)(E C: 2.7 .11 .9)$ and inositol-tetrakisphosphate 1-kinase 2-like (IT1K2) (EC:2.7.1.159; EC:2.7.1.134) genes involved in jasmonic acid stimulus were represented in cluster 2 (Figure 5C,D). AOS and Syn 121 genes involved in negative regulation of cellular defense responses were represented in cluster 3 (Figure 5E,F). LHCIIb and Entkaurene oxidase (Entkox) (EC:1.14.13.78) genes involved in photosynthesis and heme binding were represented in cluster 4 (Figure 5G,H). Salicylate o-methyltransferase (salometh) (EC 2.1.1.274) and peroxidase 15-like (peroxidase15) (EC 1.11.1.7) genes were represented in cluster 5 (Figure 5I,J). Comparison with the results of the qRTPCR analysis showed expression patterns that were significantly and consistently similar to those of the RNA-seq analysis. 


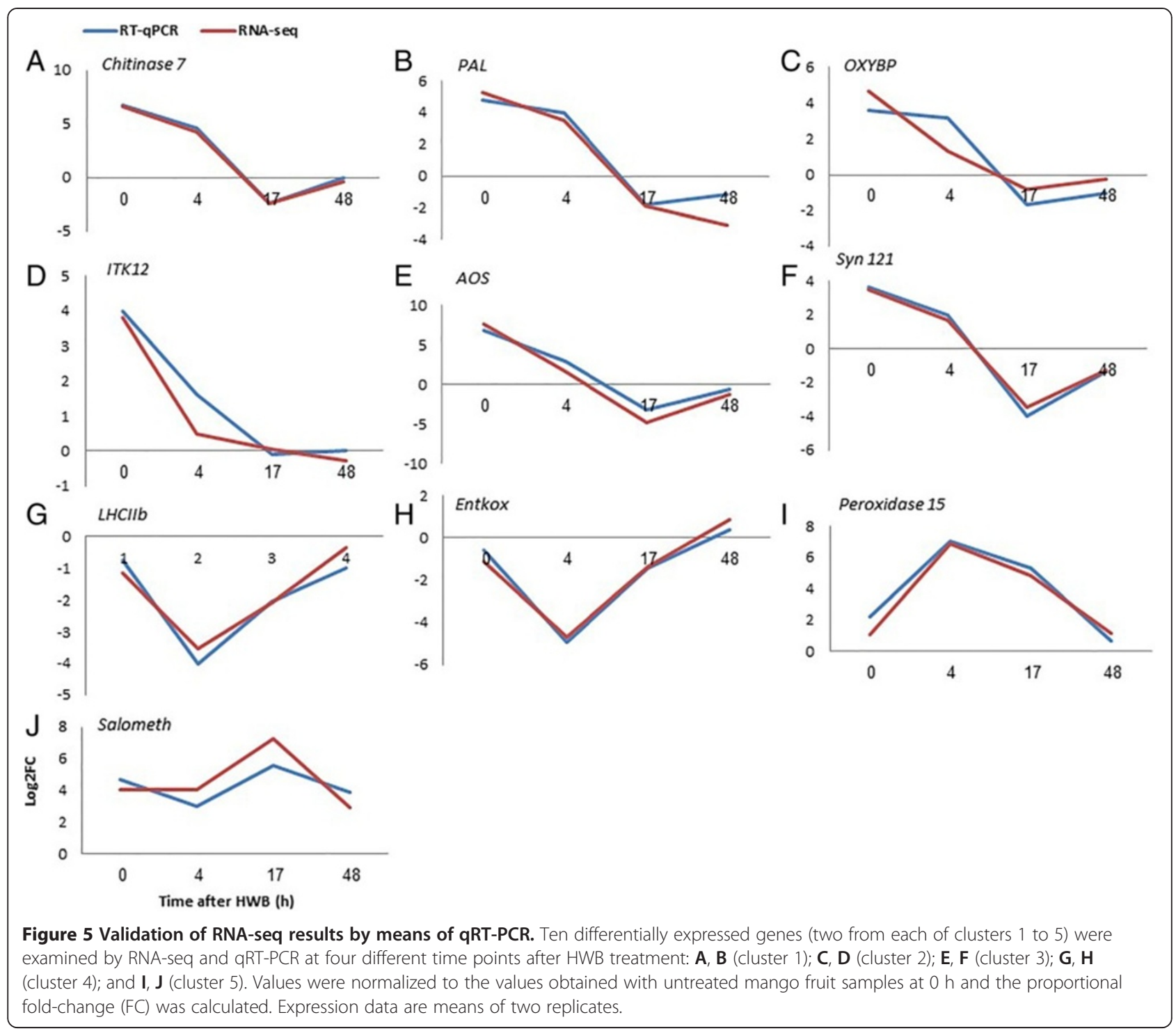

The relationships among mango fruit HWB-induced responses, disease resistance to $A$. alternata and the differential expression of genes of the different clusters HWB treatment of freshly harvested fruits reduced the incidence of natural $A$. alternata infestation on fruits of cvs. Palmer, Kent, Tommy Atkins, Keitt, Lilly and Shelly (Figure 6A). Hot water brushing treatment reduced the incidence of decay observed after 21 days of storage at $12^{\circ} \mathrm{C}$ by $64-84 \%$ (Figure $6 \mathrm{~A}$ ), as also observed in citrus [28-30] and in peaches [31]. Several genes (Figure 6C) that are known to modulate the host pathogen-resistance mechanism, related to JA and SA, showed upregulation [32-35]. Syn121 gene showed significant differential expression (Figure 5F). This gene is a member of the SNARE protein family that contributes to defense against fungal penetration [36] and might be modulated by abiotic and biotic stress responses $[37,38]$. It acts as a regulator of SA, and may contribute to host resistance in the fruit. SA contributes to systemic acquired resistance (SAR) [39] through processes that activate the hypersensitive reaction response and increased production of reactive oxygen species [40-42]. A second upregulated gene family in this group was that encoding glutaredoxin (EC 1.20.4.1). Glutaredoxin gene family is regarded as candidates for controlling the redox state of regulatory proteins [43]; they interact with TGA-transcription factors which are bZip plant transcription factors. These transcription factors contain a palindromic motif that is present in several plant promoters that are transcriptionally activated in response to elevated SA levels, and that negatively regulate the JA-inducible expression of defensin-like protein 16 (PDF1.2). Gutaredoxin is commonly used as a marker for JA-dependent defense responses [44]. 


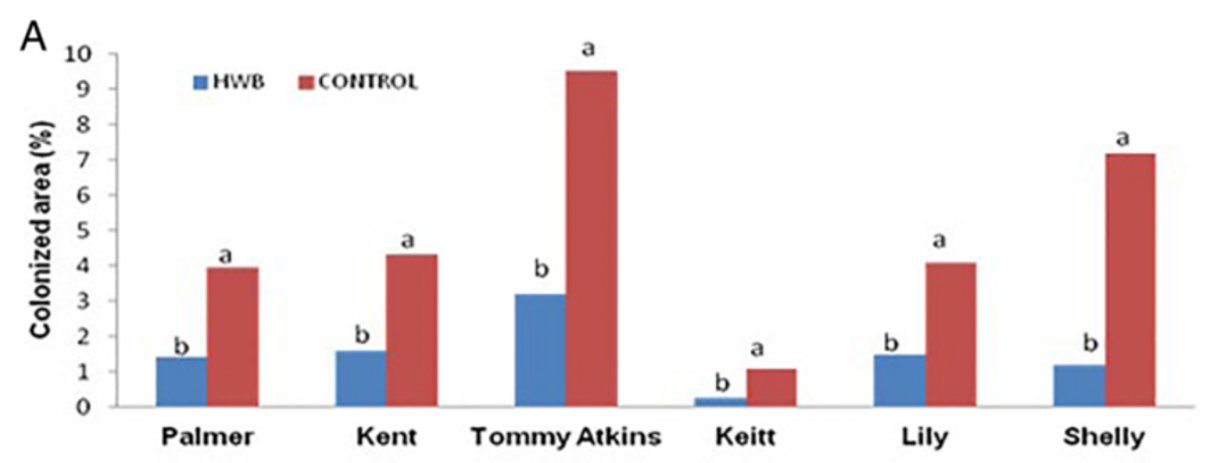

B

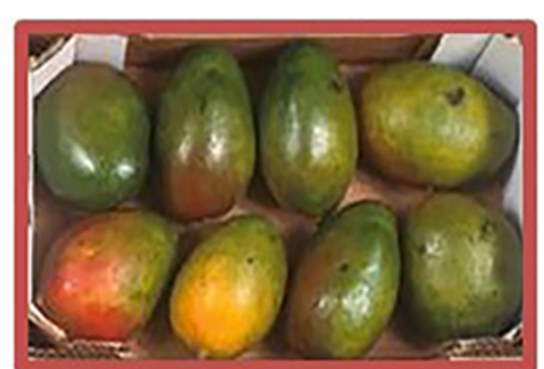

HWB

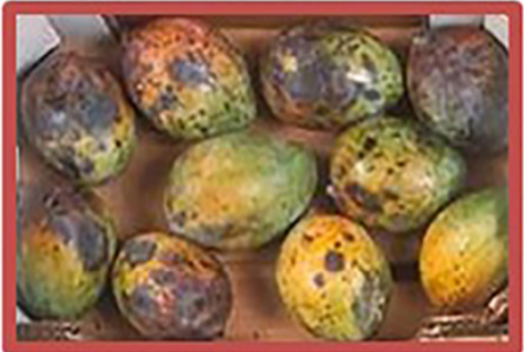

Control

C

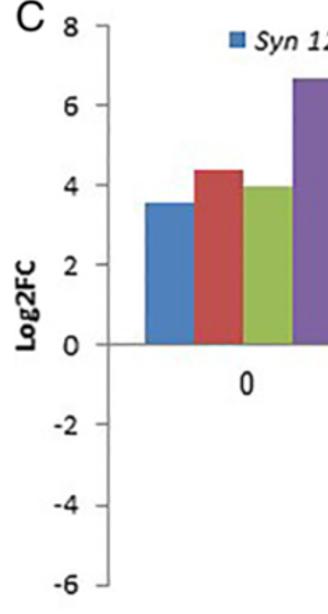

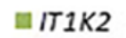

$\because A O S$

\section{Time after HWB (h)}

Figure 6 Differential expressions of genes modulating the mechanism of resistance to $A$. alternata in naturally infected mango fruits. (A) Effect of HWB on alternaria black spot (ABS) symptom development on mango cvs. Palmer, Kent, Tommy Atkins, Keitt, Lily and Shelly. (B) ABS symptom development on naturally infected fruits CV. Keitt following HWB treatment. (C) qRT-PCR differential expression profiling of genes Syn121, glutardoxin, IT1K2 and AOS of Cv. Shelly. Fruit peel tissues were sampled at four different time points after HWB treatment. RNA was extracted and served as a template for CDNA followed by qRT-PCR analysis of the genes of interest. Proportional increases in relative expression values were normalized against the samples of untreated mango fruits at $0 \mathrm{~h}$. Expression data are means of two replicates. ABS-covered area was evaluated after 4 weeks of storage at $12^{\circ} \mathrm{C}$. Average values followed by different letters differ significantly at $P<0.05$ according to the Tukey-Kramer HSD test.

Together with Syn121, glutaredoxin and IT1K2 all have a significant effect on the jasmonic acid stimulus [45,46] suggesting that the mechanism of induced resistance include JA-defense responses. Another major enzyme whose gene was upregulated was $A O S$ (Figure 5E,F), which catalyzes the first step of conversion of linoleic acid to JA. A transient increase in $A O S$ expression has been observed in wounded leaves [47] and it contributes to induced JA levels [48-50].
Changes in the metabolite content associated with the activities of ROS-scavenging enzymes were also detected in heated citrus fruits, indicating a similar possible major cellular reorganization process in those fruits, in response to the heat treatment $[28,29]$.

Aside from induction of host resistance, the presence of preformed antifungal alkylresorcinols such as resorcinol-5(12-heptadecadienyl) and resorcinol-5-(pentadecyl) $[14,15]$ is 
also a key factor modulating fruit reisitance to postharvest pathogens. These compounds are fatty-acid derivatives obtained with specialized type III polyketide synthases (referred to as 'alkylresorcinol synthases'), which catalyze the formation of 5-alkylresorcinols by using fatty acyl-CoA starter units and malonyl-CoA extension units. The polyketide synthase (PKS) enzymes involved in the biosynthesis of aromatic ring-containing intermediates as the resorcinol mainly use an aldol-condensation-based mechanism (stilbene synthasetype) or a Claisen-condensation-based mechanism (chalcone synthase-type) for ring folding [51]. A chalcone flavone isomerase involved in fatty-acid biosynthesis showed high expression at time $0 \mathrm{~h}$ after HWB, suggesting possible activation of this process by the inducing treatment.

\section{Effect of HWB on lenticel discoloration}

Lenticel discoloration results from stress induced by the HWB treatment, which leads to anthocyanin accumulation [9] (Figure 7). Four genes encoding UDPglucose flavonoid 3-o-glucosyltransferase 3-like (Ugft3) (EC 2.4.1.91) - PAL, chalcone-flavanone isomerase-like protein (CFIL) (EC 5.5.1.6) and chalcone synthase (CHS) (EC:2.3.1.74) - related to the anthocyanin accumulation, phenylpropanoid and flavonoid biosynthesis pathways found in cluster 2 were tested by qRT-PCR (Figure 7A). Increased expression of these genes was clearly observed at the 0 and $4 \mathrm{~h}$ time points, followed by decreased expression at 17 and $48 \mathrm{~h}$ after the induction treatment. 1) ugft3, was described to control anthocyanin synthesis in grapes [52]; 2) $P A L$, encodes one of the major enzymes involved in flavonoid and phenylpropanoid biosynthesis in plants, and converts Lphenylalanine to ammonia and trans-cinnamic acid, which is the precursor of the polyphenol compounds [53,54]; 3) CFIL is the second committed enzyme of the flavonoid biosynthetic pathway which enhances flavonoid production and pigmentation [55] 4) CHS, encoding chalcone synthase, which belongs to the PKSs and is also known as a type III PKS [56]; it catalyzes the initial step of flavonoid biosynthesis by converting 4coumaroyl-CoA and malonyl-CoA to naringenin chalcone [57]. Although these genes peaked relatively early $(4 \mathrm{~h})$ after the HWB treatment, we envision that they activate relevant processes modulating fruit-resistance at later stages of fruit

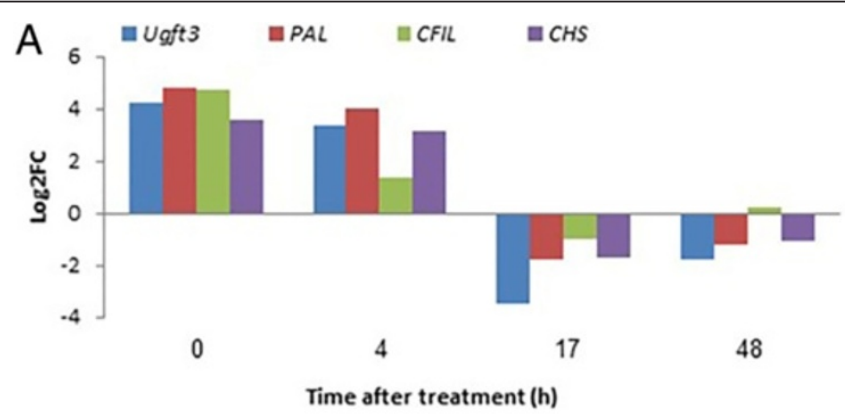

B
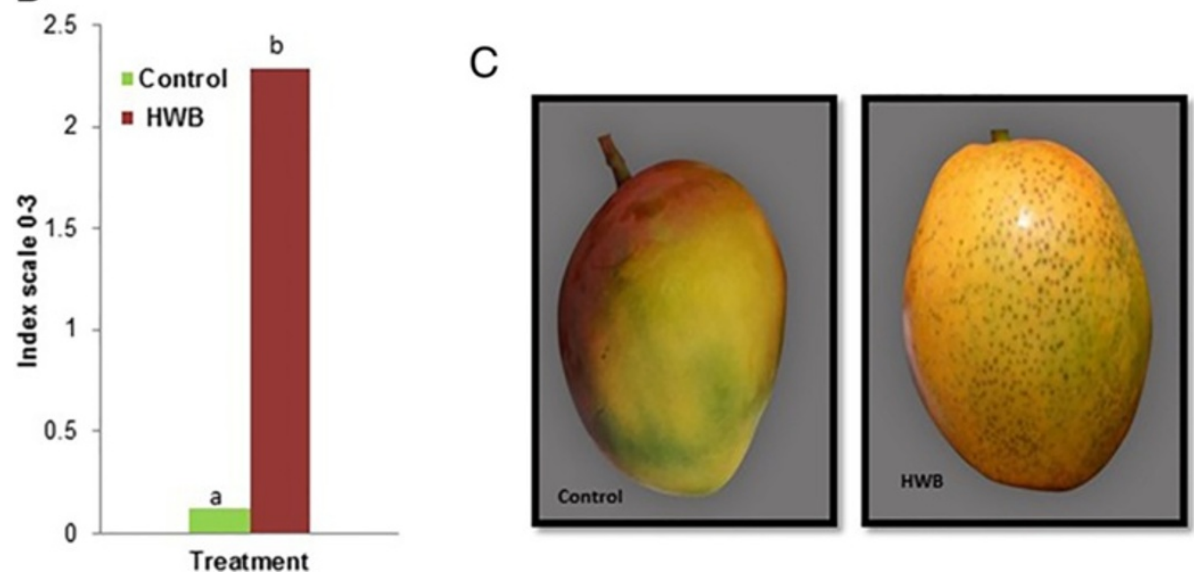

Figure 7 Effects of HWB treatment on the expression of flavonoid biosynthesis-related genes and the occurrence of red lenticel discoloration on mango fruit cv. Shelly. (A) qRT-PCR profile of differentially expressed genes Ugft3, PAL, CFIL and CHSi, which are related to the flavonoid biosynthesis process, naringenin-chalcone synthase activity, and the phenylpropanoid biosynthesis pathway. (B) level of lenticel discoloration of HWB-treated and control fruits, and (C) lenticel discoloration symptoms on mango fruits, cv. Shelly following HWB treatment. qRT-PCR values were normalized to the values obtained in samples from untreated mango fruits at $0 \mathrm{~h}$. Expression data are means of two replicates. Lenticel discoloration was evaluated following 2 weeks of storage at $12^{\circ} \mathrm{C}$ [9]. Average values followed by different letters differ significantly at $P<0.05$ according to the Tukey-Kramer HSD test. 
life. Similar phenylpropanoid pathway-expression pattern were described in heat treated peaches [58], suggesting a wide mechanism of fruit responses to heat treatment.

\section{Effect of HWB treatment on skin color change}

One of the significant consequences of HWB treatment is the improved and enhanced color development on the fruit skin, which results from both anthocyanin production and inhibition of chlorophyll accumulation. The fruit color index of HWB-treated fruits was higher during all the period of fruit storage at 12 and $20^{\circ} \mathrm{C}$ (Figure 8). The index in untreated fruits increased from values of 2.8, 16 days after harvest to $3.4,8$ days later. During the same period the HWB-treated fruits showed an increase in color index to 4.6 (Figure $8 \mathrm{C}$ ), indicating induction of a $31 \%$ increase in color level by the HWB treatment. The decreased expression of chlorophyll and anthocyanin biosynthesis-related genes suggested that HWB played a role in the modulation of those processes (Figure 8A). Reduced expression of LHCIIb encoding for chlorophyll a/b-binding protein, one of the most abundant proteins in the chloroplast, which is important in the structure of photosynthesis reaction centers $[24,25,59,60]$ indicates a reduction in chlorophyll levels. Other key genes that showed reduced expression included those encoding: the oxygen-evolving enhancer protein chloroplastic (Oxepch) (EC1.3.1.74) [61]; PIRC; and thioredoxin-like 1-chloroplastic (Thl1ch) (EC 1.1.1.49), in which the chloroplast thioredoxins have been suggested as mediators in the light-dependent regulation of chloroplast enzyme activity [62].

Two genes related to anthocyanin accumulation - anthocyanin 5-aromatic (anthocyanin5a) (EC:2.3.1.144) and UDPglycosyltransferase 85a2-like (85A2) (EC:2.4.1.115) - showed increased expression at the first two time points $(0$ and $4 \mathrm{~h})$ after HWB, as detected by qRT-PCR (Figure 8B). The anthocyanin 5 a modulates anthocyanin by aromatic acylation [63] and $85 A 2$ affects the level of glucosyl anthocyanidins in red fruit during ripening [52]. This suggests that different pathways are activated by HWB to modulate anthocyanin accumulation and to reduce processes associated with chlorophyll accumulation [64], thereby enhancing color development.

\section{Conclusions}

Overall, gene-expression profiling in mango skin revealed similarities in heat responses to those found in citrus and peach fruits $[30,58]$, with three major effects following HWB treatment: 1) a transient increase in expression of the stress- and pathogen-defense mechanisms-related genes; 2) a transient reduction in the expression of chlorophyll-related genes; and 3) increased expression of sugar and flavonoid metabolism related genes $4 \mathrm{~h}$ after treatment. These three main trends indicated by the observed HWB-induced modulation of gene expression can account for the major results of postharvest HWB treatment including: 1) induced resistance to $A$. alternata, attributed to the transient increase in the expression of genes involved in immune response and host resistance (Figure 6); 2) improved color development observed after HWB which can be attributed to decreased photosynthesis, including reduction of chlorophyll accumulation after the treatment (Figure 8) and increased abundance of genes of flavonoid metabolism; and 3) enhanced lenticel discoloration that is also correlated with upregulation of flavanoid metabolism (Figure 7).

In light of the physiological changes described, the improved fruit quality acquired following heat stress is probably a result of various stress-response mechanisms that act coordinately to improve the fruit quality, prevent pathogen development, prevent cell damage and re-establish cellular homeostasis. Genes identified in the present study that are modified in mango fruits following heat treatment, could have similar functions in other fruits such as citrus or peach.

\section{Methods}

\section{Fruit, and storage conditions}

Freshly harvested mango fruits (Mangifera indica L. cv. Shelly) were obtained from trees in commercial orchards in the north of Israel. Several experiments to determine the phenotypic response of the fruits to HWB were carried out in each season during three consecutive years. The phenotypic responses obtained in the various years were similar, therefore results from only 1 year are presented. Each treatment comprised 6 replications, each with 15 fruits.

Fruits were harvested at the commercial mature-green stage, treated on the same or the following day, and transferred to simulated export conditions. They were stored for about 4 weeks (depending on the experiment) at $12^{\circ} \mathrm{C}$, ca. $90 \% \mathrm{RH}$ [9]. Control, untreated fruits were stored under the same conditions, immediately upon arrival from the orchard.

\section{Postharvest packinghouse treatments in semi-commercial mango experiments}

Postharvest treatments were carried out at the Department of Postharvest Science of the Volcani Center in Bet Dagan, Israel. $\mathrm{HWB}$ treatment at $55^{\circ} \mathrm{C}$ was applied on the packing line, as a spray (nozzle pressure of $2 \mathrm{~atm}$ ) above brushes revolving at $60 \mathrm{~g}$, a rate of $100-120 \mathrm{~L} \mathrm{~min}^{-1}$ and at a nozzle pressure of $2 \mathrm{~atm}$ [2]. Fruits were passed over five to seven transversely oriented, 12-cm-diameter plastic brushes for 15-20 s.

\section{Fruit ripening, development of red lenticels, black spot and stem-end rots during storage}

Disease severity, measured as the percentage of the fruit surface covered by black lesions, was recorded for 90 fruits (15 fruits from each of six replicates) after about 4 weeks of storage at $12^{\circ} \mathrm{C}$ and 3 days at $20^{\circ} \mathrm{C}$. Fruits were regarded as unmarketable when more than $1 \%$ of their surface area exhibited black spots.

Lenticel spotting was assessed visually at the end of storage, on a scale of 0 to 3 , with values based on a 

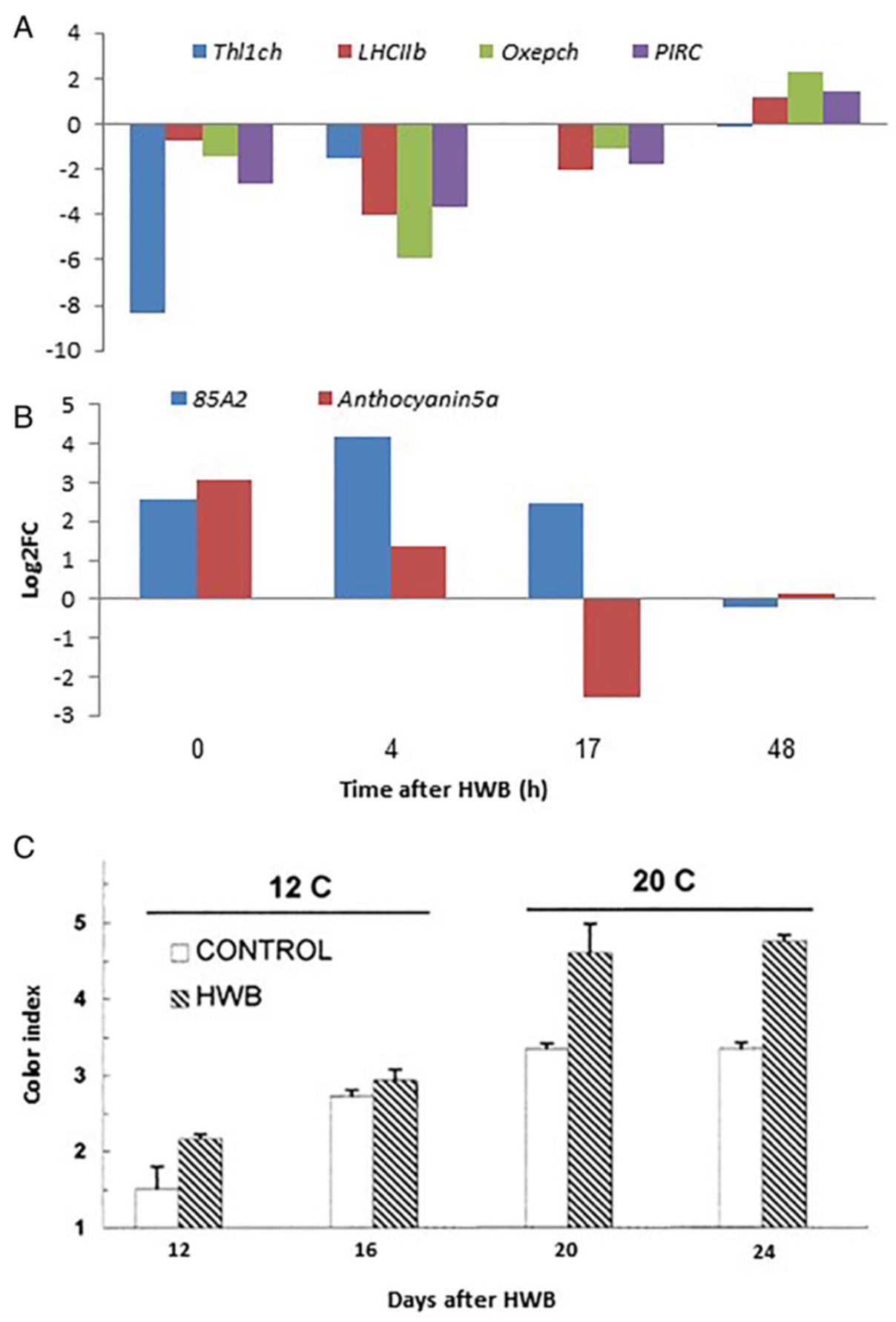

Figure 8 Shelly. Effect of HWB on differential expression of chlorophyll and anthocyanin accumulation-related genes and color development in mango cv. Shelly. (A, B) qRT-PCR gene-expression profiles of genes related to (A) chlorophyll accumulation (Th/17ch, LHCllb, Oxepch and PIRC) and (B) anthocyanin synthesis (85A2 and Anthocyanin5). The expression profile comprises data taken from samples of mango tissues sampled from cv. Shelly at four different time points after HWB treatment. (C) Changes in color index after 16 days of storage at $12^{\circ} \mathrm{C}$ followed by 8 days at $20^{\circ} \mathrm{C}$. Vertical bars indicate SD of five replicates. qRT-PCR values were normalized to the values obtained with untreated mango fruit samples at $0 \mathrm{~h}$. Expression data are the means of two replicates.

combination of degree of lenticel discoloration and area covered by the symptoms [9].

Skin color development was assessed visually at the end of storage and a color index was calculated on a scale of 1 (green) to 5 (full color) [9].

\section{Total RNA extraction}

Total RNA was extracted according to Yang et al. [65], with minor changes: about 1- to 2-g aliquots of HWB-treated and control tissues were sampled from pools composed of five different fruits from the same tree. The samples were 
ground to a fine powder in liquid nitrogen and transferred into $50-\mathrm{mL}$ centrifuge tubes with $10 \mathrm{~mL}$ of CTAB RNA ex-

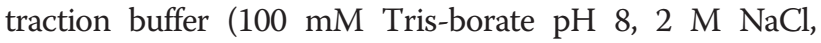
$25 \mathrm{mM}$ ethylenediaminetetraacetic acid $\mathrm{pH} \mathrm{8,2 \% (w/v)}$ CTAB, $2 \%(\mathrm{w} / \mathrm{v})$ polyvinylpolypyrrolidone and $2 \%(\mathrm{v} / \mathrm{v}) \beta-$ mercaptoethanol). The mixture was shaken for $3 \mathrm{~min}$ and then incubated at $65^{\circ} \mathrm{C}$ for $15 \mathrm{~min}$. Samples were extracted twice with an equal volume of chloroform:isoamyl alcohol $[24: 1(\mathrm{v} / \mathrm{v})]$, and the phases were separated by centrifugation at $10,000 \mathrm{~g}$ for $10 \mathrm{~min}$. Following centrifugation, lithium chloride was added to a final concentration of $2.5 \mathrm{M}$ and RNA was allowed to precipitate overnight at $4^{\circ} \mathrm{C}$. RNA was pelleted at $4^{\circ} \mathrm{C}$ for $30 \mathrm{~min}$ at $10,000 \mathrm{~g}$, washed with $70 \%$ ethanol, and re-suspended at $65^{\circ} \mathrm{C}$ for $3 \mathrm{~min}$ in SSTE buffer $(10 \mathrm{mM}$ Tris $\mathrm{pH} 8,1 \mathrm{M} \mathrm{NaCl}, 1 \mathrm{mM}$ EDTA pH 8 and $0.5 \%(\mathrm{w} / \mathrm{v})$ SDS). Samples were extracted with an equal volume of chloroform:isoamyl alcohol (24:1), and with an equal volume of chloroform:isoamyl alcohol:water-saturated phenol (24:1:25), and the phases were separated by centrifugation at $10,000 \mathrm{~g}$ for $10 \mathrm{~min}$. The RNA was ethanol-precipitated overnight, and resuspended in diethylpyrocarbonate-treated water. RNA was further treated with Turbo DNAse (Ambion, Austin, TX, USA).

\section{Analysis by qRT-PCR}

Single-stranded CDNA was synthesized from $1 \mu \mathrm{g}$ of total RNA by means of the Verso cDNA synthesis kit (Thermo Fisher Scientific, Waltham, MA, USA). The synthesized cDNA was used as a template for qRT-PCR analysis, to estimate the expression level of the selected genes. The cDNA samples were diluted 1:10 (v/v) to the final template concentration for qRT-PCR. Real-time qRT-PCR was performed with a RotorGene 3000 system (Corbett Research, Sydney, Australia). PCR amplification was run with $3.5 \mu \mathrm{L}$ of cDNA template in $10 \mu \mathrm{L}$ of reaction mixture containing $5 \mu \mathrm{L}$ absolute blue qPCR SYBR green ROX mix (Thermo Scientific) and $300 \mathrm{nM}$ primers. PCR conditions were: initial denaturing for $15 \mathrm{~min}$ at $94^{\circ} \mathrm{C}$; 40 denaturing cycles of $10 \mathrm{~s}$ at $94^{\circ} \mathrm{C}$; annealing at $60^{\circ} \mathrm{C}$ for $15 \mathrm{~s}$; extension at $72^{\circ} \mathrm{C}$ for $20 \mathrm{~s}$ (cycling A), $77^{\circ} \mathrm{C}$ for $6 \mathrm{~s}$ (cycling $\mathrm{B}$ ), or $80^{\circ} \mathrm{C}$ for $6 \mathrm{~s}$ (cycling $\mathrm{C}$ ), and melting at $72-99^{\circ} \mathrm{C}$. The samples were subjected to melting-curve analysis with the RotorGene program. All samples were normalized to actin gene levels in the same qRT-PCR, and the values were expressed as increase or decrease in level relative to a calibration sample. The forward and reverse primers for all of the genes are listed in Table 2.

Table 2 Primers used for qRT-PCR analysis

\begin{tabular}{|c|c|c|}
\hline Gene & Forward $5^{\prime} \rightarrow 3^{\prime}$ & Reverse $5^{\prime} \rightarrow 3^{\prime}$ \\
\hline Actin & CATTGTGCTCAGTGGTGGTT & TTGGAGCAAGTGCAGTGATT \\
\hline FSL & TGGGAGCATATGTTAGGGTATTGG & TCTCATCGCCTCATAATTCAAGAA \\
\hline PAL & AATGGAAATGCGGCGATTC & TCCCAGCTCTTCCCTCACAA \\
\hline CHS & GAAAGATGTTCCCGGGTTGA & AGTCGTTGATGCCGATTGG \\
\hline CFIL & GCAGTGATCCCACCACTTGA & TCATGCATTCGTACATCTGTAGCA \\
\hline Oxybp & CAATTCGACGGAACCGAATC & CCGTTCCCTACCAAGTCGTTT \\
\hline IT1K2 & AACTATTTCCCTGGGTATGGGAA & CTGACTCTGTTTCAGGCCCAA \\
\hline Chitinase 7 & CATTCAAGACTGCCCTGTGGTA & GGCTCGAATAGTTGCACCAAA \\
\hline Hlich & TGCAACACCAAAGCAACAAAC & TCCCACCATCTAAGAGACCTACTG \\
\hline PIRCS & AGTCTAACGCTGACAGGAAGGAA & AATCCACCAGCGAACTTGGA \\
\hline LHCIlb & GGGCTATGCTTGCTGTTCCA & AGCCCACTCTTGAGCCTITACC \\
\hline $85 A 2$ & CAAGCTTCATGAGAGTCACTGATG & GAAGATTTCAAGCAGTCGTGTGAT \\
\hline Entkox & TGGCAGTGAGATTGCCGTAA & CAGGCCTCCACACGTTAGGAT \\
\hline Salometh & ACTCACCATCACCAAGCGAAA & TTGTGTAATCTCAGTCCGATCAATC \\
\hline Syn 121 & TGCGGTCCAGGATCTTCATC & TCCATCGAGTCCTGCAACTTC \\
\hline Glutaredoxin & GGGAAGATGGTTTCCGAGAAT & AGCAAACGCTTCACCACATG \\
\hline AOS & AGAGCAGAGGAGTTCGTGGC & TGGTCCGTTTGACCACAGC \\
\hline Peroxidase15 & TGCCCAGGAGTTGTCTCTTGT & CAGGTTTGACCTCCATCCAAA \\
\hline Ugft3 & CTCATCTGCAATCCAGAAATCG & AATCGAGTGTCGCGGTTTG \\
\hline Thl1ch & TGCAACACCAAAGCAACAAAC & TCCCACCATCTAAGAGACCTACTG \\
\hline Oxepch & GCCACGTCTCGAACATTAAGC & TACACTGCCGTCGTCTTCTTGA \\
\hline Anthocyanin5 & TाTCTCACTTCCCTGCTTTGG & TCCGGCGTCATTACAGATGA \\
\hline
\end{tabular}




\section{Bioinformatics analysis of RNA-seq data}

The transcriptome of $M$. indica cv. Shelly was sequenced according to Illumina Hiseq2000 and Trueseq protocols, at the Crown Institute for Genomics, The Nancy and Stephen Grand Israel National Center for Personalized Medicine at the Weizmann Institute of Science, Rehovot, Israel. Eight libraries with total single-end RNA-seq reads 100 nucleotides in length were generated. The eight libraries contained the following sequences: 1 ) control RNA-seq of mango peel at time $0 \mathrm{~h}$ with 20,025,080 reads; 2) RNA-seq of mango peel treated by HWB at time 0 h with 20,202,891 reads; 3 ) control RNA-seq of mango peel at time $4 \mathrm{~h}$ with 21,622,332 reads; 4) RNAseq of mango peel $4 \mathrm{~h}$ after HWB with 20,744,762 reads; 5) control RNA-seq of mango peel at $17 \mathrm{~h}$ with 20,916,444 reads; 6) RNA-seq of mango peel $17 \mathrm{~h}$ after HWB with 21,410,839 reads; 7) control RNA-seq of mango peel at $48 \mathrm{~h}$ with 20,687,358 reads; and 8) RNAseq of mango peel $48 \mathrm{~h}$ after HWB with 21,230,696 reads. The transcriptome datasets are available in the NCBI Sequence Read Archive (SRA) under accession number SRX375390 and BioProject accession PRJNA227243. A new transcriptome was assembled from the 8.6-Gbp sequences by using Trinity software [66], generating 57.544 contigs with N50 of 1,598 bp. This Transcriptome Shotgun Assembly project has been deposited at DDBJ/EMBL/GenBank under accession no. GBCV00000000. The version described in the present paper is the first version, GBCV01000000.

Tophat [67], Bowtie2 [68] and Cufflink packages [67] were used to align the RNA-seq with the transcriptome and to calculate differentially expressed genes. The libraries were aligned with the mango transcriptome at alignment rates (mapped reads/total reads) of 90.84, 90.02, 89.48, 89.77, 90.70, 90.11, 90.25 and $90.35 \%$ for samples 1 to 8 , respectively.

The genes of $M$. indica cv. Shelly were annotated by using BLASTx [69], after which their GO term [70] was assigned by combining both BLASTx data and interproscan analysis [71] by means of the BLAST2go software pipeline [72]. GO-enrichment analysis was performed by using Fisher's exact test with multiple testing correction of FDR. Heat mapping and clustering of the genes were performed with the $\mathrm{R}$ software ggplots2 package [73].

\section{Additional files}

Additional file 1: Table S1. Table of differentially expressed genes and their annotations after HWB treatment versus control at time $0 \mathrm{~h}$.

Additional file 2: Table S2. Table of differentially expressed genes and their annotations after HWB treatment versus control at time $4 \mathrm{~h}$.

Additional file 3: Table S3. Table of differentially expressed genes and their annotations after HWB treatment versus control at time $17 \mathrm{~h}$.
Additional file 4: Table S4. Table of differentially expressed genes and their annotations after HWB treatment versus control at time $48 \mathrm{~h}$

Additional file 5: Table S5. GO enrichment analysis of gene clusters [74].

\section{Abbreviations}

HWB: Hot-water brushing; OxyBP: Oxysterol-binding protein; IT1K2: Inositoltetrakisphosphate 1-kinase 2-like; AOS: Allene oxide synthase;

Syn 121: Syntaxin-121-like; LHCllb: Chlorophyll a/b-binding protein chloroplastic-like; PIRCS: Photosystem I reaction center subunit chloroplasticlike; 85A2: UDP-glycosyltransferase 85a2-like; PAL: Phenylalanine ammonia lyase; CFIL: Chalcone-flavanone isomerase-like protein; CHS: Chalcone synthase; Entkox: Ent-kaurene oxidase; Salometh: Salicylate omethyltransferase; Ugft3: UDP-glucose flavonoid 3-o-glucosyltransferase; Th/1ch: Thioredoxin-like 1- chloroplastic; Oxepch: Oxygen-evolving enhancer protein chloroplastic.

\section{Competing interests}

The authors declare that they have no competing interests.

\section{Authors' contributions}

NL performed the experiments and drafted the manuscript. NS performed the bioinformatics analyses and drafted the manuscript. MY performed the RNA extractions and initial qPCR quantification. OF and IK performed the HWB and sampling of fruits. AL helped with the analysis and writing of the manuscript. DP conceived the project, supervised the project, and drafted the manuscript. All authors have read and approved the final manuscript.

\section{Acknowledgments}

This study was supported in part by a grant from the Chief Scientist of the Israeli Ministry of Agriculture and Rural Development.

\section{Author details}

${ }^{1}$ Department of Postharvest Science of Fresh Produce, ARO, the Volcani Center, Bet Dagan 50250, Israel. ${ }^{2}$ Department of Plant Pathology and Weed Research, ARO, the Volcani Center, Bet Dagan 50250, Israel.

Received: 13 February 2014 Accepted: 23 October 2014

Published: 5 November 2014

\section{References}

1. Brecht JK, Sargent SA, Kader AA, Mitcham EJ, Maul F, Brecht PE, Menocal O: Mango Postharvest Best Management Practices Manual. Gainesville: Univ. of Fla. Horticultural Sciences Department; 2010. Publ. HS1185. 78 pp.

2. Prusky D, Fuchs Y, Kobiler I, Roth I, Weksler A, Shalom Y, Fallik E, Zauberman $G$, Pesis E, Akerman M: Effect of hot water brushing, prochloraz treatment and waxing on the incidence of black spot decay caused by Alternaria alternata in mango fruits. Postharvest Biol Technol 1999, 15(2):165-174.

3. Kader A, Mitcham B: Optimum procedures for ripening mangoes. In Fruit Ripening and Ethylene Management, Univ. Calif. Postharvest Technology Research and Information Center Publication Series, Volume 9; 2008.

4. Pesis E, Aharoni D, Aharon Z, Ben-Arie R, Aharoni N, Fuchs Y: Modified atmosphere and modified humidity packaging alleviates chilling injury symptoms in mango fruit. Postharvest Biol Technol 2000, 19(1):93-101.

5. Prusky D, Fuchs $Y$, Yanko U: Assessment of latent infections as a basis for control of postharvest disease of mango. Plant Dis 1983, 67(7):816-818.

6. Prusky D, Fuchs $Y$, Zauberman G: A method for pre-harvest assessment of latent infections in fruits. Ann Appl Biol 1981, 98(1):79-85.

7. Prusky D, Shalom Y, Kobiler I, Akerman M, Fuchs Y: The level of quiescent infection of Alternaria alternata in mango fruits at harvest determines the postharvest treatment applied for the control of rots during storage. Postharvest Biol Technol 2002, 25(3):339-347.

8. Yahia EM: Modified and controlled atmospheres for tropical fruits. Stewart Postharvest Rev 2006, 2(5):1-10.

9. Feygenberg O, Keinan A, Kobiler I, Pesisa E, Lersa A, Prusky D, Feygenberg $\mathrm{O}$, Keinan A, Kobiler I, Pesisa E, Lersa A, Prusky D: Improved management of mango fruits by orchard and in packing house treatments for the reduction of lenticels discoloration and decay prevention. Postharvest Biol Technol 2014. in press. 
10. Du Plooy W, Combrinck S, Botha B, Van der Merwe C, Regnier T: Development of discolouration in mango lenticels. Acta Horticult 2006, 820:665-672.

11. Prusky D: Pathogen quiescence in postharvest diseases. Annu Rev Phytopathol 1996, 34(1):413-434.

12. Kobiler I, Shalom Y, Roth I, Akerman M, Vinokour Y, Fuchs Y, Prusky D: Effect of 2,4-dichlorophenoxyacetic acid on the incidence of side and stem-end rots in mango fruits. Postharvest Biol Technol 2001, 23(1):23-32.

13. Prusky D, Eshel D, Kobiler I, Yakoby N, Beno-Moualem D, Ackerman M, Zuthji Y, Ben Arie R: Postharvest chlorine treatments for the control of the persimmon black spot disease caused by Alternaria alternata. Postharvest Biol Technol 2001, 22(3):271-277.

14. Droby S, Prusky D, Jacoby B: Induction of an antifungal agent in unripe mango fruits to demonstrate their involvement in latent infections of Alternaria alternata. Physiol Mol Plant Pathol 1987, 30:285-292.

15. Droby S, Prusky D, Jacoby B, Goldman A: Presence of an antifungal compound and its relation to the latency of Alternaria alternata in unripe peel of mango fruits. Physiol Mol Plant Pathol 1986, 29:173-183

16. Davidzon M, Kobiler I, Alkan N, Prusky D: Acidification of fruit environment by gluconic acid during decay development of Phomopsis mangiferae. Postharvest Biol Technol 2009, 55(2):71-77.

17. Singh N: A Draft Genome of the King of Fruit, Mango (Mangifera indica L). In Plant and Animal Genome XXII Conference, Plant and Animal Genome; 2014

18. Grabherr MG, Haas BJ, Yassour M, Levin JZ, Thompson DA, Amit I, Adiconis X, Fan L, Raychowdhury R, Zeng Q: Full-length transcriptome assembly from RNA-Seq data without a reference genome. Nat Biotechnol 2011, 29(7):644-652.

19. Ashburner M, Ball CA, Blake JA, Botstein D, Butler H, Cherry JM, Davis AP, Dolinski K, Dwight SS, Eppig JT: Gene ontology: tool for the unification of biology. Nat Genet 2000, 25(1):25-29.

20. Howe GA, Schilmiller AL: Oxylipin metabolism in response to stress. Curr Opin Plant Biol 2002, 5(3):230-236.

21. Winkel-Shirley B: Flavonoid biosynthesis. A colorful model for genetics, biochemistry, cell biology, and biotechnology. Plant Physio/ 2001, 126(2):485-493.

22. Mitsch MJ, Voegele RT, Cowie A, Osteras M, Finan TM: Chimeric structure of the NAD (P) + -and NADP + -dependent malic enzymes ofRhizobium (Sinorhizobium) meliloti. J Biol Chem 1998, 273(15):9330-9336.

23. Maekawa S, Inada N, Yasuda S, Fukao Y, Fujiwara M, Sato T, Yamaguchi J: The $\mathrm{C} / \mathrm{N}$ regulator ATL31 controls papilla formation in response to powdery mildew fungi penetration by interacting with SNARE SYP121 in Arabidopsis. Plant Physiol 2014, 113:230995

24. Paulsen H, Dockter C, Volkov A, Jeschke G: Folding and Pigment Binding of Light-harvesting Chlorophyll a/b Protein (LHCIlb). In: The Chloroplast. Springer: 2010:231-244

25. Szabó I, Bergantino E, Giacometti GM: Light and oxygenic photosynthesis: energy dissipation as a protection mechanism against photo-oxidation. EMBO Rep 2005, 6(7):629-634

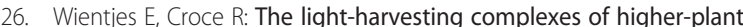
Photosystem I: Lhca1/4 and Lhca2/3 form two red-emitting heterodimers. Biochem J 2011, 433:477-485.

27. Bengis C, Belson N: Subunit structure of chloroplast photosystem I reaction center. J Biol Chem 1977, 252(13):4564-4569.

28. Perotti VE, Del Vecchio HA, Sansevich A, Meier G, Bello F, Cocco M, Garrán SM, Anderson C, Vázquez D, Podestá FE: Proteomic, metabalomic, and biochemical analysis of heat treated Valencia oranges during storage. Postharvest Biol Technol 2011, 62(2):97-114.

29. Sapitnitskaya M, Maul P, McCollum GT, Guy CL, Weiss B, Samach A, Porat R: Postharvest heat and conditioning treatments activate different molecular responses and reduce chilling injuries in grapefruit. J Exp Bot 2006, 57(12):2943-2953.

30. Yun Z, Gao H, Liu P, Liu S, Luo T, Jin S, Xu Q, Xu J, Cheng Y, Deng X: Comparative proteomic and metabolomic profiling of citrus fruit with enhancement of disease resistance by postharvest heat treatment. BMC Plant Biol 2013, 13:44.

31. Lauxmann MA, Brun B, Borsani J, Bustamante CA, Budde CO, Lara MV Drincovich MF: Transcriptomic profiling during the post-harvest of heat-treated Dixiland Prunus persica fruits: common and distinct response to heat and cold. PLoS One 2012, 7(12):e51052.
32. Dixon RA, Harrison MJ, Lamb CJ: Early events in the activation of plant defense responses. Annu Rev Phytopathol 1994, 32(1):479-501.

33. Jones JD, Dangl JL: The plant immune system. Nature 2006 444(7117):323-329.

34. Keen NT: Gene-for-gene complementarity in plant-pathogen interactions. Annu Rev Genet 1990, 24:447-463.

35. Ponce De León I, Montesano M: Activation of defense mechanisms against pathogens in mosses and flowering plants. Int J Mol Sci 2013, 14(2):3178-3200

36. Shukla S, Srivastava P, Choubey SK: Comparative analysis and structure elucidation of Syntaxin-A novel component tends to defense mechanism in plant proteomics. Saurabh Shukla1, Prashant Srivastava1, Sanjay Kumar Choubey1 and Gomase VS 2. 2010.

37. Kunkel BN, Brooks DM: Cross talk between signaling pathways in pathogen defense. Curr Opin Plant Biol 2002, 5(4):325-331.

38. Wasternack C, Hause B: Jasmonates and octadecanoids: signals in plant stress responses and development. Prog Nucleic Acid Res Mol Biol 2002, 72:165-221.

39. Ryals JA, Neuenschwander UH, Willits MG, Molina A, Steiner H-Y, Hunt MD: Systemic acquired resistance. Plant Cell 1996, 8(10):1809.

40. Mur LAJ, Bi YM, Darby RM, Firek S, Draper J: Compromising early salicylic acid accumulation delays the hypersensitive response and increases viral dispersal during lesion establishment in TMV-infected tobacco. Plant J 1997, 12(5):1113-1126.

41. Mur LAJ, Brown IR, Darby RM, Bestwick CS, Bi YM, Mansfield JW, Draper J: A loss of resistance to avirulent bacterial pathogens in tobacco is associated with the attenuation of a salicylic acid-potentiated oxidative burst. Plant J 2000, 23(5):609-621.

42. Shirasu K, Nakajima H, Rajasekhar VK, Dixon RA, Lamb C: Salicylic acid potentiates an agonist-dependent gain control that amplifies pathogen signals in the activation of defense mechanisms. Plant Cell Online 1997, 9(2):261-270.

43. Lemaire SD, Guillon B, Le Maréchal P, Keryer E, Miginiac-Maslow M, Decottignies P: New thioredoxin targets in the unicellular photosynthetic eukaryote Chlamydomonas reinhardtii. Proc Natl Acad Sci U S A 2004 101(19):7475-7480.

44. Brown RL, Kazan K, McGrath KC, Maclean DJ, Manners JM: A role for the GCC-box in jasmonate-mediated activation of the PDF1.2 gene of Arabidopsis. Plant Physiol 2003, 132(2):1020-1032.

45. Mosblech A, Thurow C, Gatz C, Feussner I, Heilmann I: Jasmonic acid perception by COI1 involves inositol polyphosphates in Arabidopsis thaliana. Plant J 2011, 65(6):949-957.

46. Sheard LB, Tan X, Mao H, Withers J, Ben-Nissan G, Hinds TR, Kobayashi Y Hsu F-F, Sharon M, Browse J: Jasmonate perception by inositolphosphate-potentiated COI1-JAZ co-receptor. Nature 2010, 468(7322):400-405.

47. Laudert D, Pfannschmidt U, Lottspeich F, Holländer-Czytko H, Weiler EW: Cloning, molecular and functional characterization of Arabidopsis thaliana allene oxide synthase (CYP 74), the first enzyme of the octadecanoid pathway to jasmonates. Plant Mol Biol 1996, 31(2):323-335.

48. Hamberg M: Biosynthesis of 12-oxo-10, 15 (Z)-phytodienoic acid: identification of an allene oxide cyclase. Biochem Biophys Res Commun 1988, 156(1):543-550.

49. Laudert D, Hennig P, Stelmach BA, Müller A, Andert L, WE W: Analysis of 12-oxo-phytodienoic acid enantiomers in biological samples by capillary gas chromatography-mass spectrometry using cyclodextrin stationary phases. Anal Biochem 1997, 246(2):211-217.

50. Vick BA, Zimmerman DC: Lipoxygenase, hydroperoxide isomerase, and hydroperoxide cyclase in young cotton seedlings. Plant Physiol 1981 67(1):92-97.

51. Baerson SR, Schroder J, Cook D, Rimando AM, Pan Z, Dayan FE, Noonan BP, Duke SO: Alkylresorcinol biosynthesis in plants: new insights from an ancient enzyme family? Plant Signal Behav 2010, 5(10):1286-1289.

52. Ford CM, Boss PK, Hoj PB: Cloning and characterization of Vitis vinifera UDP-glucose:flavonoid 3-O-glucosyltransferase, a homologue of the enzyme encoded by the maize Bronze- 1 locus that may primarily serve to glucosylate anthocyanidins in vivo. J Bio/ Chem 1998, 273(15):9224-9233.

53. Camm EL, Towers G: Phenylalanine ammonia lyase. Phytochemistry 1973, 12(5):961-973

54. Jones DH: Phenylalanine ammonia-lyase: regulation of its induction, and its role in plant development. Phytochemistry 1984, 23(7):1349-1359. 
55. Morita Y, Takagi K, Fukuchi-Mizutani M, Ishiguro K, Tanaka Y, Nitasaka E, Nakayama M, Saito N, Kagami T, Hoshino A: A chalcone isomerase-like protein enhances flavonoid production and flower pigmentation. Plant J 2014, 78(2):294-304.

56. Austin MB, Noel JP: The chalcone synthase superfamily of type III polyketide synthases. Nat Prod Rep 2003, 20(1):79-110.

57. Ferrer JL, Jez JM, Bowman ME, Dixon RA, Noel JP: Structure of chalcone synthase and the molecular basis of plant polyketide biosynthesis. Nat Struct Biol 1999, 6(8):775-784.

58. Lauxmann MA, Borsani J, Osorio S, Lombardo VA, Budde CO, Bustamante CA Monti LL, Andreo CS, Fernie AR, Drincovich MF: Deciphering the metabolic pathways influencing heat and cold responses during post-harvest physiology of peach fruit. Plant Cell Environ 2014, 37(3):601-616.

59. Bellafiore S, Barneche F, Peltier G, Rochaix JD: State transitions and light adaptation require chloroplast thylakoid protein kinase STN7. Nature 2005, 433(7028):892-895.

60. Niyogi KK, Li XP, Rosenberg V, Jung HS: Is PsbS the site of non-photochemical quenching in photosynthesis? J Exp Bot 2005, 56(411):375-382.

61. Mayfield SP, Rahire M, Frank G, Zuber H, Rochaix J-D: Expression of the nuclear gene encoding oxygen-evolving enhancer protein 2 is required for high levels of photosynthetic oxygen evolution in Chlamydomonas reinhardtii. Proc Natl Acad Sci 1987, 84(3):749-753.

62. Buchanan BB, Wolosiuk RA, Schürmann P: Thioredoxin and enzyme regulation. Trends Biochem Sci 1979, 4(4):93-96.

63. Fujiwara $H$, Tanaka Y, Fukui $Y$, Nakao M, Ashikari T, Kusumi T: Anthocyanin 5-aromatic acyltransferase from gentiana triflora. Eur J Biochem 1997, 249(1):45-51.

64. Ishida S, Takabayashi A, Ishikawa N, Hano Y, Endo T, Sato F: A novel nuclear-encoded protein, NDH-dependent cyclic electron flow 5, is essential for the accumulation of chloroplast $\mathrm{NAD}(\mathrm{P}) \mathrm{H}$ dehydrogenase complexes. Plant Cell Physiol 2009, 50(2):383-393.

65. Yang G, Zhou R, Tang T, Shi S: Simple and efficient isolation of highquality total RNA from Hibiscus tiliaceus, a mangrove associate and its relatives. Prep Biochem Biotechnol 2008, 38(3):257-264.

66. Haas BJ, Papanicolaou A, Yassour M, Grabherr M, Blood PD, Bowden J, Couger MB, Eccles D, Li B, Lieber M: De novo transcript sequence reconstruction from RNA-seq using the Trinity platform for reference generation and analysis. Nat Protoc 2013, 8(8):1494-1512.

67. Trapnell C, Roberts A, Goff L, Pertea G, Kim D, Kelley DR, Pimentel H, Salzberg SL, Rinn JL, Pachter L: Differential gene and transcript expression analysis of RNA-seq experiments with TopHat and Cufflinks. Nat Protoc 2012, 7(3):562-578.

68. Langmead B, Salzberg SL: Fast gapped-read alignment with Bowtie 2. Nat Methods 2012, 9(4):357-359.

69. Altschul SF, Gish W, Miller W, Myers EW, Lipman DJ: Basic local alignment search tool. J Mol Biol 1990, 215(3):403-410.

70. Gene Ontology C, Blake JA, Dolan M, Drabkin H, Hill DP, Li N, Sitnikov D, Bridges S, Burgess S, Buza T, McCarthy F, Peddinti D, Pillai L, Carbon S, Dietze H, Ireland A, Lewis SE, Mungall CJ, Gaudet P, Chrisholm RL, Fey P, Kibbe WA, Basu S, Siegele DA, McIntosh BK, Renfro DP, Zweifel AE, Hu JC, Brown NH, Tweedie S, et al: Gene ontology annotations and resources. Nucleic Acids Res 2013, 41(Database issue):D530-D535.

71. Hunter S, Apweiler R, Attwood TK, Bairoch A, Bateman A, Binns D, Bork P Das U, Daugherty L, Duquenne L, Finn RD, Gough J, Haft D, Hulo N, Kahn D, Kelly E, Laugraud A, Letunic I, Lonsdale D, Lopez R, Madera M, Maslen J, McAnulla C, McDowall J, Mistry J, Mitchell A, Mulder N, Natale D, Orengo C, Quinn AF, et al: InterPro: the integrative protein signature database. Nucleic Acids Res 2009, 37(Database issue):D211-D215.
72. Conesa A, Gotz S, Garcia-Gomez JM, Terol J, Talon M, Robles M: Blast2GO: a universal tool for annotation, visualization and analysis in functional genomics research. Bioinformatics 2005, 21(18):3674-3676.

73. R Development Core Team: R: A Language and Environment for Statistical Computing. Vienna, Austria: R Foundation for Statistical Computing; 2009.

74. Benjamini $Y$, Hochberg $Y$ : Controlling the false discovery rate: a practical and powerful approach to multiple testing. J R Stat Soc Ser B (Methodol) 1995, 57(1):289-300.

doi:10.1186/1471-2164-15-957

Cite this article as: Luria et al:: De-novo assembly of mango fruit peel transcriptome reveals mechanisms of mango response to hot water treatment. BMC Genomics 2014 15:957.

\section{Submit your next manuscript to BioMed Central and take full advantage of:}

- Convenient online submission

- Thorough peer review

- No space constraints or color figure charges

- Immediate publication on acceptance

- Inclusion in PubMed, CAS, Scopus and Google Scholar

- Research which is freely available for redistribution

Submit your manuscript at www.biomedcentral.com/submit
C) Biomed Central 